\title{
UTILISING TECHNOLOGY IN HEALTH SCIENCES EDUCATION
}

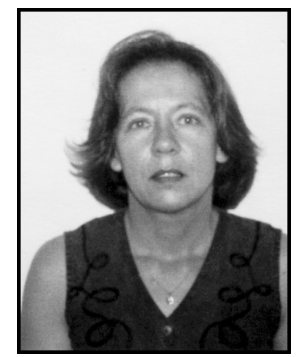

\section{Louise De Villiers}

D Litt et Phil (Unisa)

Lecturer, Department of Advanced Nursing Sciences, UNISA

Key terms: Educational technology, cognitive competence, information skills, critical paradigm, cognitive development learning perspective, socio-cultural learning theory, mediated learning, curriculum

\section{SUMMARY}

Health sciences education is rendered within a context that is characterised by knowledge and technological explosions. This is associated with the utilisation of technology in education. It is proposed that the use of technology should occur within the framework of a sound educational strategy. The aim of such a strategy would be to develop cognitive competence in learners. The critical paradigm is regarded to provide a suitable philosophical foundation for such an educational strategy. This would support adopting a learning theory that is associated with the cognitive development learning perspective. According to this perspective the role of the educator is conceptualised in terms of mediation. The curriculum would support problem based, media based, co-operative and reflective learning. Curriculum implementation ought to occur in an interactive, critical, democratic and collaborative learning climate. Suggestions on how to utilise information technology in health sciences education are discussed.

\section{OPSOMMING}

Gesonheidswetenskappe-onderwys word gelewer in 'n konteks wat gekenmerk word deur kennis en tegnologiese ontploffings. Dit word geassosieer met die benutting van tegnologie in onderwys. Daar word voorgestel dat die benutting van tegnologie sal geskied binne die raamwerk van 'n grondige opvoedkundige strategie. Die doel van so 'n strategie sal die ontwikkeling van kognitiewe bevoegdheid by leerders wees. Die kritiese paradigma word beskou as 'n geskikte filosofiese grondslag vir so 'n opvoedkundige strategie. Dit ondersteun die aanvaarding van 'n leerteorie wat verband hou met die kognitiewe ontwikkeling leerperspektief. Kragtens die perspektief kan die rol van die opvoedkundige gekonseptualiseer word in terme van bemiddeling. Die kurrikulum ondersteun probleemgerigte, mediagerigte, koöperatiewe en reflektiewe leer. Kurrikulumimplementering geskied in ' $n$ interaktiewe, kritiese, demokratiese en medewerkende leerklimaat. Voorstelle oor die benutting van inligtingtegnologie in gesondheidswetenskappeonderwys, word bespreek.

\section{INTRODUCTION}

The context of health sciences education is characterised by realities that are inherent in an information technology-driven global order, the socalled post-industrial era (Esterhuyse, 1995:19; Tanner, 1995:247). The post-industrial era is characterised by constant and revolutionary changes resulting in a demand for health practitioners who are able to think critically and function in complex, ever changing environments. Health professionals are required to be technologically literate, exhibit a global vision, and possess the skills to seek, access, select and interpret information and 
apply it appropriately. Knowledge explosions in science and technology result in situations where people cannot depend on previously successful ideas. New knowledge and ideas should constantly be pursued and therefore health professionals should be committed to life long learning (Esterhuyse, 1995:19; Malan, 1999:59).

Traditionally, educational practices are based on the empirical analytical curriculum development paradigm whereby the development of technical skills for a particular vocation is emphasised (Arjun, 1998:23; Gwele, 1996:27-28). This goes hand in hand with a focus on the transmission of content and thought processes with immediate practical value. This approach is applicable to the demands of the industrial era, but not to that of the postindustrial era. The latter requires that learners' thought processes, information skills and learning skills are developed in contrast to a mere mastering of content and technical skills (Slabbert, 1994:38-39).

One way of developing learners' thought processes, information skills and learning skills would be to adopt an educational strategy that supports the utilisation of information technology in education. The basic premise of this paper is that cognitive competence is required to utilise information technology in the quest for learning in the educational setting or role performance in a technologically advanced world. I will propose that it is necessary to view the aspect of the utilisation of technology in health sciences education within the context of a broader educational strategy aimed at developing, amongst others, cognitive competence in learners. This proposition is in line with the view by Malan (1999:63), namely that the didactical value of technology as an educational tool must be emphasised and technology itself.

COGNITIVE COMPETENCE AS A PREREQUISITE FOR UTILISING TECHNOLOGY IN EDUCATION AND PRAC-

\section{TICE}

Cognitive competence is described by Fry (1992:3) as a range of diverse contents including cognitive skills, cognitive processes, motivations for success, goal-directedness in activities, and interest in a range of progressively complex levels of cognitive ability such as thinking, reasoning and problemsolving. Cognition refers to, to know namely the acquisition, organisation and application of knowledge. It encompasses all the processes through which learners acquire knowledge such as perceiving, remembering and reasoning (Lefrancois, 1997:157-158; Monteith, 1994:90). Cognitive processes include thinking, understanding and communicating (Halpern, 1996:21). Metacognition is an individual's insights into his/her own cognitive abilities such as memory and thinking processes and utilisation of these insights during the learning process. It refers to cognitive knowing strategies such as setting of objectives, assessing whether additional information ought to be acquired, evaluating a learning strategy that is being utilised and self-monitoring. Metacognition enables the learner to plan learning activities based on an understanding of the demands of a particular learning task, learning objectives and variables that influence learning (Halpern, 1996:34; Monteith, 1994:90-91). Metacognitive knowledge is a prerequisite for accepting self-responsibility for learning (Woolfolk, 1990:253).

Fry (1992:3-4) proposes that the components of cognitive competence are overt behaviours, cognitive processes and cognitive structures. Overt behaviours include skills in working with and relating to others and also behaviours pertaining to self-control and regulation. Cognitive processing refers to the skills associated with self-appraisals, goal expectancies, metacognition, information processing and problem-solving. The concept cognitive structures refers to the learner's meaning systems, as well as his/her perceptions of anxiety and stress or current concerns that he/she engenders 
with respect to performance tasks (Fry, 1992:5-7). Cognitive structure is a network of current concepts, strategies and insights in the mind, representing existing knowledge of the learner. A learner's cognitive structure serves as an interpretative framework according to which new information is processed to ensure meaningful learning (Lefrancois, 1997:157). There are therefore interrelationships between an individual's behaviour, intellectual thought processes and meaning making processes that lead to an extension of his/her cognitive structure of knowledge.

The principal dimensions of cognitive competence include a composite of cognitive and metacognitive knowledge and skills development in areas of learning, thinking, reasoning, problem-solving, self-efficacy, self-regulation and self-management. $\mathrm{Cog}$ nitive competence entails higher order cognitive skills and competencies such as a strategic approach to learning, thinking and reasoning, the ability to think in the abstract, ability to use and extract feedback from environmental resources and the capacity for behavioural and cognitive self-regulation in determining and attaining goals. A cognitive competent person is able to combine information, knowledge and skills to go beyond the given information, to draw inferences about things yet to be encountered and to connect and probe for connections (Fry, 1992:IX). Persons who use higher order thinking skills tend to think at a conceptual level rather than by rote memorisation (De Villiers, 1998:205). According to Vockel (in De Villiers, 1998:205), higher order thinking skills comprise overlapping categories such as metacognition, critical and creative thinking, and thinking skills such as classification, analysis and synthesis.

It is clear from the above that cognitive competence constitutes intellectual abilities such as skills pertaining to reasoning and problem solving, learning and reflecting, as well as knowledge construction through a process of meaning making. It also entails social skills such as the ability to collabo- rate with others while exercising self-discipline. The discussions also brought to light that cognitive competence has an emotional dimension. An educational strategy aimed at the development of cognitive competence in learners should therefore include a focus on the intellect, the emotions and the social nature of learning.

\section{EDUCATIONAL PARADIGM FOR DE- VELOPING COGNITIVE COMPE- TENCE IN LEARNERS}

The critical paradigm could be adopted as the educational foundation for health sciences education aimed at preparing learners to learn and ultimately function in technologically advanced environments. Its fundamental interest is social transformation for a better, more just society through emancipation and empowerment of people to engage in autonomous actions arising out of authentic, critical insights into the social construction of human society (Freire, 1972:20, 30-31; Grundy, 1987:18, 99, 106; Rajah, 1993:99-100).

The focus is on helping people to gain insights into the power structures within society and ideological domination of the people that results in powerlessness (Grundy, 1987:19; Lovat \& Smith, 1995:29-31). Within the context of health sciences education, educators and learners are encouraged to gain understandings of the current state of affairs with regard to utilising technology for educational purposes in a particular country and the factors contributing to such a state of affairs.

Individuals and groups are empowered to shape their own destinies by encouraging them to question current ideas in order to free themselves of ungrounded beliefs and attitudes (Siegel in Bandman \& Bandman, 1995:7). Within the context of health sciences education, learners and educators ought to be encouraged to question the social and political factors that hamper development towards effective utilisation of technology in health 
sciences education.

The individual is empowered to engage in autonomous, but responsible actions (Freire, 1972:24; Grundy, 1987:19, 113). This entails actions to effect changes to a current state of affairs (Lovat \& Smith, 1991:105). Within the context of health sciences education, learners ought to be encouraged to reflect upon how society shaped their perceptions about themselves and their abilities to shape their own destinies (in a professional sense) by contributing towards changes that could result in improved education and ultimately health care delivery in their country. They should also be encouraged to question their own perceptions about their capabilities to overcome existing problems with regard to access to technology in education such as financial and infrastructure limitations. Clarity ought to be sought about the value of their contributions in establishing a better dispensation by means of active and committed participation in social change, which could include lobbying for and establishing an infrastructure that would support the utilisation of technology in education. There are various problems that inhibit the utilisation of technology in education in developing countries. However the benefits outweigh the problems by far. Hopefully health professionals will view potential problems in terms of challenges, which, once overcome, would enable the health professionals of the African continent to participate in the global quest to prepare practitioners who would be able to render health care of the highest possible standard.

The basic disposition of the critical paradigm is critical reflection (Grundy, 1987:124), a process of constructing and reconstructing the world reflectively through a process of meaning making. This is achieved through dialectic interactions between actions and reflections that the individual engages in, thus promoting understandings of the world (Freire, 1972:99; Grundy, 1987:104, 113, 115). Grundy (in Ford \& Profetto-McGrath, 1994:342) describes these interactions as follows: "Action is informed by reflection, and reflection is informed by action. Praxis is not action that maintains the status quo, but rather action that changes both the world and our understanding of it." With regard to action Freire (1972:29) says: “...but action is human only when it is not merely an occupation but also a preoccupation, that is, when it is not dichotomised from reflection." Within the context of health sciences education, the educator must therefore ensure that learners are engaged in actions pertaining to achieving learning objectives, as well as critical reflections to enhance their understandings of the principles and influences underlying these actions.

From the perspective of the critical paradigm learning is regarded to be a social process, characterised by dialogue and negotiations (Grundy, 1987:102$107,115)$. It is a social construction of personal knowledge through a process of internalisation (Cobb in Gravett \& Henning, 1998:61). The learning process centres around social issues and realities in the real world. Learning occurs in concrete situations and requires actions as well as intellectual responses. A critical focus is maintained and learning is regarded to be a process of interpretations and meaning-making (Grundy, 1987:103; Rajah, 1993:99). Within the context of health sciences education, learning is reality based in the sense that it centres around health sciences practice. It is the role of the educator to ensure that realities encountered in practice are used as the points of departure and focal points of the learning process.

It is clear from the above that educators and learners should be empowered to contribute towards the establishment of an educational system that supports the utilisation of information technology in education. Learning ought to centre around real life issues that health professionals are faced with, and reflective involvement of learners in the learning process should be promoted by the educator. 


\section{A LEARNING PERSPECTIVE}

Considering the previous discussions about cognitive competence and the critical educational paradigm, it is further proposed that learning could be viewed in terms of a cognitive development learning perspective.

\section{The cognitive development learning perspec- tive}

The individual is regarded to be a social being that learns and develops in interaction with others. He/ she is an active, purposeful being who possesses a potential for personal development (Fry, 1992:IX). Cognitive development of the individual is enhanced by interacting with others while conducting relevant tasks (Dillenbourg, Baker, Blaye \& O’Malley, 1994:1; Doise in Kumar, 1996a:1). Learning is a social process that occurs within a co-operative learning environment that is characterised by dialogue and collaboration. Through collaboration shared conceptions of a problem is constructed by learners. This ensures that learners acquire the necessary knowledge and skills, and gain insights into the circumstances (context) within which the acquired knowledge and skills are to be applied (Kumar, 1996:1-2).

A related learning theory is the socio-cultural theory of Vygotsky (Kumar, 1996:1).

\section{Vygotsky's socio-cultural learning theory}

Vygotsky (1978:88) views learning as a socio-cultural process, whereby learners grow into the intellectual life of those around them. Mental functions such as thinking, reasoning, problem-solving or logical memory are looked upon, not only in terms of individual development, but more predominantly in terms of potential for growth when functioning in collaboration with other expert adults and peers (Fry, 1992:53). Intelligence is viewed in terms of the way in which people learn rather than the level of learning that they have achieved in some point of time (Vygotsky in Halpern, 1996:22).

The focus of Vygotsky's theory is the child. However, the theory could also be applied to adult learners given the fact that human development is an ongoing process. Health sciences education is specifically concerned with learners' development towards higher levels of professional maturity.

There are differences in the levels of professional maturity between novice learners and expert learners in a particular social context. Within the context of health sciences education, the educator (expert learner) has achieved higher levels of cognitive competence than the novice learners (learners). However, in some respects he/she is also a co-learner. The novice learners have the potential to achieve, through guidance by the expert learner, higher levels of cognitive competence that will enable them to gain increasing levels of independence with respect to, for instance, problem-solving or utilisation of technology to achieve learning objectives.

Vygotsky (1978:86-87) distinguishes between the actual and the potential levels of development of a learner at any given point in time. The actual level of development is characterised by those activities that the learner can do independently as a result of completed development cycles. The potential level of development refers to those activities that the learner can do under guidance or mediation of an adult or more capable peer. The zone of proximal development is the distance between the actual and the potential levels of development of the learner. The larger the zone of proximal development, the greater the potential for growth. The educator operates within the learners' zone of proximal development. Diagnostic evaluation occurs at the lower limit and practical teaching towards the upper end of the zone (Fry, 1992:IX, 59). The central mechanism for learning is transfer of responsibility from the educator to the learners. 
There is a causal relationship between social interactions and cognitive development of the individual. Through social interactions, the external social world of the individual is linked to his/her internal mental processes through the process of mediation. Mediation occurs within the zone of proximal development to promote progress towards the potential levels of development of the learner. The consequence of mediation is progress towards higher levels of cognitive abilities. Learning has occurred when internalisation has taken place. Internalisation is manifested in the ability to carry out, independently in similar settings, the skills that the learner has acquired in collaboration with others. The learner should also be able to apply what he/she has learnt, independently to similar problems (Kumar, 1996:1; Vygotsky, 1978:56-57; Wertsch \& Stone, 1985:166).

An individual uses language to attach meaning to his/her experiences. It is through language that thoughts and ideas are exchanged between individuals. Such an exchange leads to combining the ideas and experiences of various persons to enhance learning. Meaning is therefore socially and culturally grounded. The implication for education is that meaningful dialogue is promoted during the learning process (Wink, 1997:82-88).

The above discussions indicate that an educational strategy that allows for the utilisation of information technology ought to include strategies to promote the intellectual development of learners in a social context that is characterised by meaningful dialogue. It also requires that the role of the educator be conceptualised as a mediator who functions within the zones of proximal development of learners to facilitate their development towards higher levels of development and transferring the responsibility for independent learning to learners.

\section{PROPOSED EDUCATIONAL STRATEGIES}

Proposed educational strategies include strategies associated with problem based learning, media based learning, co-operative learning and experiential learning. The central focus when applying these strategies would be the development of information skills in learners.

\section{Developing information skills in learners}

Effective utilisation of information technology in education and practice requires information skills. Learning activities should therefore be structured to promote the development of information skills in learners. Learners ought to be guided through a process of seeking, accessing, interpreting and applying information systematically and appropriately. Such a structure is proposed in table 1 .

It is further proposed that teaching and learning aimed at developing information skills in learners ought to support the principles of problem-based, media-based, co-operative and reflective learning.

\section{Problem based learning}

Barrows and Tamblyn (in Ross, 1991:34) defines problem based learning as: “... the learning which results from the process of working towards the understanding of, or resolution of, a problem." Barrows (in Creedy, Horsfall \& Hand, 1992:727) says: "Problem based teaching methodologies demonstrate the complementary nature of theory and practice that promotes conceptual understanding, development of reasoning skills, and self-directed learning strategies."

The aims of problem based learning are the acquisition of recallable and usable knowledge, self-directed learning skills and clinical reasoning skills (Barrows, 1986:481; Barrows in Townsend, 1990:61).

Problem based learning provides a link between the conceptual structure of existing knowledge in the mind of learners and actions for the achievement of learning objectives in the classroom or 
Table1: Proposed structure of learning experiences.

\begin{tabular}{|c|c|}
\hline PHASES & STEPS \\
\hline $\begin{array}{l}\text { Phase } 1 \\
\text { Preparation }\end{array}$ & 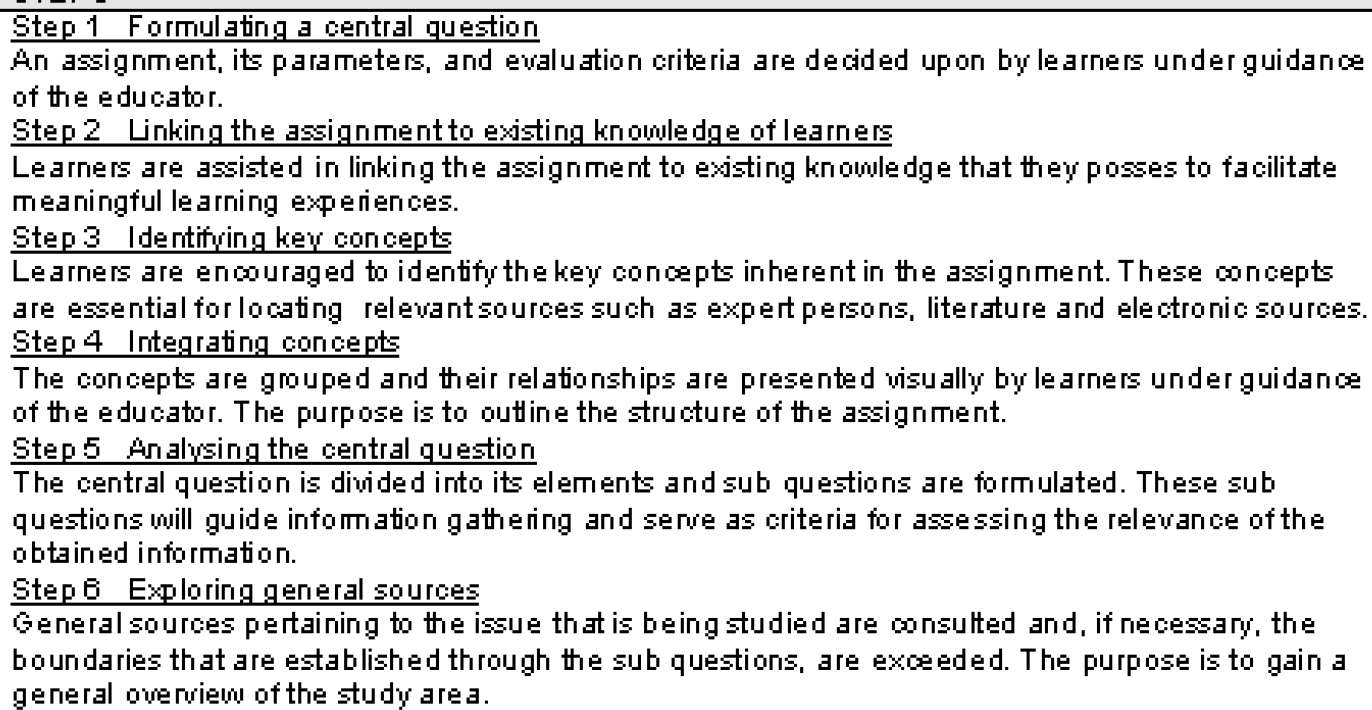 \\
\hline $\begin{array}{l}\text { Phäe } 2 \\
\text { Seanohing } \\
\text { for } \\
\text { information }\end{array}$ & $\begin{array}{l}\text { Step } 7 \text { Qbtaining relevant sources } \\
\text { The concept that have been identified in step } 3 \text { seno as guidelines for obtaining relevant sourees. } \\
\text { These include electronic sources and other media, literature and expert persons. } \\
\text { Step } 8 \text { Searching for relevant information } \\
\text { The sources are worked turough and relevant infomation is gattered and noted. }\end{array}$ \\
\hline $\begin{array}{l}\text { Phヨヨe } 3 \\
\text { Interpret:ti } \\
\text { هח }\end{array}$ & $\begin{array}{l}\text { Stepg Selecting and assessing relevant information } \\
\text { The notes that have been compiled in the previous step are analysed to determine whether they are } \\
\text { relewant to the stated assignment question. The sub questions senue as oriteria for relevanos. The } \\
\text { information is further assessed for recency, objectivity, consistency and darity. } \\
\text { Step } 10 \text { Interpreting } \\
\text { During this step, learners have to understand relationships, and make inferences and condusions. }\end{array}$ \\
\hline $\begin{array}{l}\text { Phase } 4 \\
\text { Application }\end{array}$ & 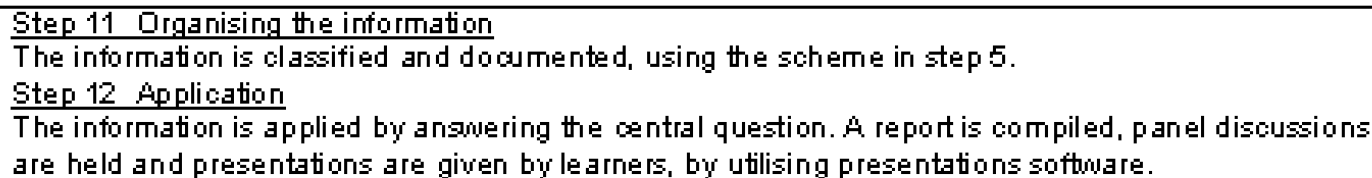 \\
\hline
\end{tabular}

clinical settings. Learners link problems and issues that they are confronted with to their cognitive structures of existing knowledge through the process of critical reflections. This leads to conflicts between learners' current knowledge and the learning problem that has to be solved (Posner et al. in Creedy et al. 1992:731, 132). Learners then identify knowledge gaps that would hamper their learning. It is then up to them to independently seek the knowledge that is needed to address the problem successfully. The educator creates psychological discomfort in learners by placing obstacles in their way. Learners are encouraged to take risks to overcome these obstacles (Creedy et al. 1992:729-730). While grappling with the problem, learners search for knowledge that is required to approach the problem in a meaningful manner (Ross, 1991:36). This leads to an extension of their existing cognitive structures. Knowledge and problem-solving skills acquired by learners are tested experimentally in similar situations leading to repetitions of the process (Creedy et al. 1992:729-732; Ford \& ProfettoMcGrath, 1994:341-343).

Problem based learning rests mainly on the principle of self-directed learning (Barrows, 1986:482; Creedy et al. 1992:729; Townsend, 1990:61). Learners are allowed to practise discovery learning within a structured learning environment (Van Niekerk \& Van Aswegen, 1993:39-40).

Learning occurs in a rapidly changing society characterised by knowledge and technological explosions. Therefore, the development of information skills and technological skills (pertaining to information technology) in learners is essential. Media, with an emphasis on information technology, are important sources of information on which 
problem-solving is based. Therefore, learning activities should require that learners seek information independently using, amongst others, information technology.

\section{Media based learning}

Media, with an emphasis on information technology, are important sources of information on which problem-solving is based. Media based learning refers to planned learning opportunities that give learners indirect exposure to reality, and provide interactive learning experiences (Hugo, 1992:99). Media based learning is problem based rather than information based. Media is regarded to be the sources of knowledge and the role of the educator is that of planner and organiser of learning opportunities. Learners engage interactively in the learning situation. They acquire new knowledge in interaction with a variety of sources, the educator and their peers. A multimedia approach is adopted by combining media such as the computer, slides, audio, books and magazines (Hugo, 1992:99).

\section{Computer assisted learning}

Computer assisted learning is any of a wide range of educational techniques whereby the computer is used to facilitate learning (Quinn, 1995:226).

The multimedia computer refers to a computer that simultaneously incorporates the characteristics of a computer, television, video recorder, telephone, compact disk player and radio (Bowen, 1995:8). Interactive learning experiences could be provided through a multimedia computer or the Internet (Hannah in Quinn, 1995:226). A given topic could be presented to learners in the form of text, video, animation, sound and graphics. Learners have the freedom to follow any of several possible routes of interrelated topics in their quest of knowledge construction. They are enabled to study an issue according to their own needs and to branch to interrelated topics, video clips, animation or sound clips by clicking on a relevant hypertext with the com- puter mouse (Bowen, 1995:8; Quinn, 1995:226).

Personal experience in establishing a computer centre at a nursing college brought to light that that a holistic approach ought to be adopted when providing learners access to computers.

Firstly, courses aimed at developing learners' basic computer literacy ought to be established. This would include introductory computer skills, typing skills, and skills required to utilise word-processing, data base, presentations and Internet software efficiently and appropriately. Learners should also be taught how to seek information using electronic dictionaries, encyclopaedias and the Internet.

Secondly, supporting services should be put in place. This could include giving learners access to computers, scanners and printers to type assignments, develop their presentations and to use the Internet.

Thirdly, remedial education could be provided in a computer centre. For instance, learners could be assisted in upgrading their language proficiency by using professionally developed interactive software packages (Quinn, 1995:226). This is especially important in countries where learners study in their second or third language.

Fourthly, learners should have access to professional medical software, such as electronic anatomy and physiology programs. These packages can frequently be upgraded by purchasing upgrade packages or downloading upgrades from the Internet. It would, for instance, be beneficial to learners to work through a multimedia computer program on heart sounds just before they are required to perform a physical examination of a patient. Simulation software gives learners the opportunity to experience reality technologically. This would allow for developing the ability to analyse complex situations, manage crises and to manage conflict (Van Niekerk, 1993:47). An example is a computer program that simulates an emergency department. Learners are 
required to select a simulated patient, conduct assessments, identify a health problem and decide upon relevant interventions. The reaction of the simulated patient would depend upon the learner's choices. A wrong decision would lead to the death of the simulated patient. This provides a safe environment for developing clinical judgement abilities in learners.

Modern technology also enables learners to communicate with peers and field experts on a global basis, thus allowing for the development of a global vision in learners and gaining access to authoritative knowledge.

Another strategy would be to develop on-line courses whereby virtual classrooms are established on the Internet.

\section{Co-operative learning}

Co-operative learning is based on the assumption that learning is a social process and that interactions with others awaken internal development processes in an individual (Bitzer, 1999:11-12).

Learners are interdependent upon one another and collaborate to achieve shared learning objectives. Each group member is accountable to the group. Interactions between learners are characterised by mutual support and encouragement. Knowledge and ideas are shared and learners learn how to present and defend arguments (Johnson \& Johnson, 1991:57-58).

There are several dimensions of co-operative learning. Firstly there are clear objectives that provide a focus for co-operation. Secondly, sharing of ideas and mutual support occur in a learning climate in which dialogue could flourish. Thirdly, all the group members are actively involved and each one is awarded the opportunity to fulfil a leadership role at some point in time. Fourthly, power is equally distributed. Power is based on expertise, access to information and competence in relation to a specific learning task. Every member has equal opportunities to fulfil a position of authority at some point in time. The fifth dimension is that of flexible decision-making. Depending on the specific situation, decision-making could be based on consensus, majority vote or decision-making by the most authoritative figure. Lastly, conflict is seen as something that ought to be managed in the interest of creative decision-making (Johnson \& Johnson, 1994:24-27, 99-101, 133-135, 145, 240244, 401, 411).

\section{Experiential learning}

Reflective involvement of learners could be promoted by applying the principles of experiential learning. This means that the learning experiences should be structured so that learners are accompanied through the phases of experiential learning, namely concrete experience, reflective observation, abstract conceptualisation, and active experimentation (Kolb, 1984:40).

\section{THE LEARNING CLIMATE}

I further propose that learners ought to achieve learning objectives in an interactive, collaborative, democratic and critical learning climate.

The dimensions of learning are both analytical and emotional and the learning climate therefore rests on intellectual and affective pillars. Learners must be confronted with intellectual challenges in a nonthreatening, democratic environment in which they feel secure enough to take some risks that are necessary for engaging in dialogue and reflective discussions (Gravett \& Henning, 1998:62). The development of a critical disposition is promoted by stimulating learners' inquisitiveness and encouraging them to take risks while devising creative solutions to problems, or address given issues creatively. An interactive learning climate requires interactions and dialogue among learners, between 
learners and the educator, as well as interactions between learners and the learning material. Collaboration and interdependence ought to be sought within the context of a democratic learning climate in which all concerned are co-learners whose needs are to be addressed and whose contributions are to be respected.

\section{THE MEDIATING ROLE OF THE EDU- CATOR}

Cognitive development is deemed necessary for learners to gain competence necessary for meaningful participation in a technologically advanced world. As previously explained, this could be achieved within the cognitive development learning perspective. In line with the stated learning perspective, it is proposed that the role of the educator could be conceptualised in terms of a mediator implementing the principles of mediated learning and dialogic mediation to promote self-directed learning by learners. Mediated learning will therefore be explored.

\section{Feuerstein's theory of mediated learning ex- perience}

According to Feuerstein's (1980:15-17) theory of mediated learning experience, learning occurs through a process of mediation. An expert learner (the educator) acts as mediator between a novice learner and his/her external environment to enhance intellectual development of the novice learner. External stimuli that a learner is exposed to, influence his/her behaviour and cognitive orientation. Mediated learning occurs when stimuli in the external environment of the learner are purposefully selected and transformed by a mediating agent to enhance learning (Feuerstein, 1980:15-16). A mediating agent intentionally influences interactions between the learner and his/her environment in a way that facilitates the learner's ability to organise and interpret the given events (Fry, 1992:94). The mediator interprets, directs and gives meaning to the stimuli that the learner is confronted with, to enhance effective learning (Feuerstein et al. in Mentis \& Frielick, 1993:104; Vygotsky, 1978:1314). Sources of stimulation include the mediator's own level of education and cognitive competencies, for example the ability to think, reason, analyse, as well as his/her qualities such as nurturing and commitment (Fry, 1992:96). The external world of the novice learner is linked to his/her internal cognitive processes with the purpose of effecting behavioural changes and the development cognitive schemata that would enable the learner to derive maximum benefit from direct exposure to various sources of stimulation (Fry, 1992:96). These changes, in turn, lead to changes in the learner's interactions with his/her environment (Feuerstein, 1980:15-17).

The learner is exposed to dimensions of experience that transcend immediate needs and that are important for more complex, remote aspects of cognitive development thus enhancing further developments towards higher levels of cognitive competence (Fry, 1992:97).

\section{Dialogic mediation}

Gravett and Henning (1998:61) propose an approach whereby teaching is viewed in terms of being a learning centred, co-learning process of dialogic mediation whereby knowledge is jointly constructed by the educator and learners (Gravett \& Henning, 1998:62). It is a process in which the educator, learners and knowledge are in a dynamic reciprocal unity. The educator is regarded to be a mediator between learners' current ways of thinking and doing, and the body of public (disciplinary) knowledge with its concomitant way of thinking and doing that learners need to appropriate and internalise (Gravett \& Henning, 1998:61). The educator creates the context in which dialogue and mediation could flourish. The mediator is a colearner, guide and democratic authority. The relationship between the mediator and learners are 
characterised by co-operation, mutual respect and learning centeredness (Gravett \& Henning, 1998:61-62).

\section{Promoting self-directed learning}

The role of the nurse educator as mediator goes hand in hand with the promotion of self-directed learning. Self-directed learning could be promoted by correlating the educator's involvement in the teaching-learning situation with the learners' learning stage at a particular point in time and to promote development towards a more advanced stage. Independent actions should be encouraged and the educator should only mediate where guidance by a more able peer is required. He/she should also retreat as the novice learner's abilities for independent practise develop.

\section{CONCLUSION}

In this article it is proposed that the utilisation of information technology in health sciences education should be planned and implemented within the context of an educational strategy aimed at developing cognitive competence in learners. Cognitive competence is needed to enable a person to learn and function in a technologically advanced environment. Educational strategies and a learning climate for the development of information skills in learners and allowing for learning in a social context were discussed. The role of the educator was conceptualised in terms of mediation. The assumption is that the utilisation of information technology to achieve learning objectives would contribute towards the abilities of learners to utilise technology in the health care setting.

\section{REFERENCES}

Arjun, P 1998: An evaluation of the proposed new curricula for schools in relation to Kuhn's conception of paradigms and paradigm shifts. South African Journal

for Higher Education, 12(1): 20-26.
Bandman, EL \& Bandman, B 1995: Critical thinking in nursing; second edition. Connecticut: Appleton \& Lange.

Barrows, HS 1986: A taxonomy of problem-based learning methods. Medical Education, 20: 481-486.

Bevis, EO \& Watson, J 1989: Toward a caring curriculum. A new pedagogy for nursing. New York: NLN.

Bitzer, EM 1994: Collaborative learning as instructional strategy. South African Journal for Higher Education, $8(2)$ : 40-44.

Bitzer, EM 1999: Pitfalls and bridges: Co-operative and collaborative learning in higher education. South African Journal for Higher Education, 13(1): 11-17.

Bowen, A 1995: More than a PC. SA Computer Buyer, 3(11): 8-20.

Chow, C 1987: Information skills curriculum guide. Process, scope and sequence. Washington: Library Media Association.

Creedy, D; Horsfall, J \& Hand, B 1992: Problem based learning in nursing education: An Australian view. Journal of Advanced Nursing, 17: 727-733.

De Villiers, MR 1998: Instructional theories of experts: A practical implementation. SA Journal for Higher Education, 12(2): 204-214.

Dillenbourg P; Baker, M; Blaye, A \& O’Malley, C 1994: The evolution of research on collaborative learning. http:/ /tecfa.unige.ch/tecfa-research/lhm/ESF-Chap5.text

Esterhuyse, W 1995: Tussen twee wêrelde. Finansies en Tegniek, 17 Maart 1995: 19.

Feuerstein, R 1980: Instrumental enrichment: An intervention program for cognitive modifiability. Baltimore: University Park Press.

Ford, JS \& Profetto-McGrath, J 1994: A model for criti- 
cal thinking within the context of curriculum as praxis. Journal of Nursing Education, 33(8): 341-344.

Freire, P 1972: Pedagogy of the oppressed. Harmondsworth: Penguin.

Fry, PS 1992: Fostering children's cognitive competence through mediated learning experiences. Frontiers and futures. Springfield: Charles C Thomas

Gravett, S \& Henning, E 1998: Teaching as dialogic mediation: A learning centred view of higher education.

SA Journal for Higher Education, 12(2): 60-68.

Grundy, S 1987: Curriculum: Product or praxis. Philadelphia: Falmer Press.

Gwele, NS 1996: The process-product dichotomy in education: Relevance to nursing education. Curationis, 19(1): 27-32.

Halpern, DF 1996: Thought and knowledge: An introduction to critical thinking; third edition. Mahwah: Lawrence Erlbaum.

Hugo, J 1992: Mediagesteunde leer. Suid-Afrikaanse Tydskrif vir Hoër Onderwys, 6(3): 97-103.

Johnson, DW \& Johnson, FP 1991: Co-operative learning and classroom and school climate. (In: Fraser, BJ \& Walberg, HJ eds. 1991: Educational environments. Evaluation, antecedents and consequences. Oxford: Pergamon Press, pp.55-74.)

Kolb, DA 1984: Experiential learning experience as the source of learning and development. Prentice Hall: Englewood Cliffs.

Kumar, VS 1996: Theories of learning and cognition in collaboration. http://www.cs.usask.ca/grads/ vsk719/ academic/890/ project2/node7.html p.1-2.

Lefrancois, GR 1997: Psychology for teaching; ninth edition. London: Wadsworth Publishing Company.
Lovat, TJ \& Smith, DL 1991: Curriculum: Action on reflection. Wentworth Falls: Social Science Press.

Lovat, TJ \& Smith, DL 1995: Curriculum: Action on reflection revisited; third edition. Wentworth Falls: Social Science Press.

Malan, SPT 1999: Imperatives for technology-enhanced delivery systems for providing education in South Africa. South African Journal for Higher Education, 13(1): 59-63.

Mentis, M \& Frielick, S 1993: Teaching thinking and thinking teaching: Adaptations of Feuerstein's cognitive theories in a university setting. South African Journal for Higher Education Research Supplement, 7(1): 101-109.

Monteith, JL de K 1994: Metakognisie, leerstrategieë en motivering vir doeltreffende leer. Suid-Afrikaanse Tydskrif vir Hoër Onderwys, 8(1): 90-93.

Quinn, FM 1995: The principles and practice of nursing education; third edition. London: Chapman \& Hall.

Rajah, DS 1993: Paradigms in teacher education. South African Journal for Higher Education, 7(1): 95-102.

Ross, B 1991: Towards a framework for problem-based curricula. (In: Boud, D \& Feletti, G eds. 1991: The challenge of problem based learning. London: Kogan Page, pp.34-41.)

Slabbert, JA 1994: Metalearning and education for all. South African Journal for Higher Education, 8(1): $38-41$.

Tanner, CA 1995: Editorial: The times they are achangin'. Journal of Nursing Education, 34(6): 247.

Townsend, J 1990: Problem based learning. Nursing Times, 86(14): 61-62.

Van Niekerk, LJ 1993: Onderwystegnologie as ‘n Golem. 
Suid-Afrikaanse Tydskrif vir Hoër Onderwys, 7(3):

42-48.

Van Niekerk, K \& Van Aswegen, E 1993: Implementing problem based learning in nursing. Nursing RSA, 8(5): 37-41.

Vygotsky, LS 1978: Mind in society. The development of higher psychological processes; M Cole et al. London: Harvard University Press.

Wertsch, JV \& Stone, CA 1985: The concept of internalisation in Vygotsky's account of the genesis of higher mental functions. (In: Wertsch, JC ed. 1985: Culture, communication and cognition. New York: Cambridge University Press.)

Wink, J 1997: Critical pedagogy: Notes from the real world. New York: Longman.

Woolfolk, AE 1990: Educational psychology; fourth edition. Boston: Allyn \& Bacon. 